donnatrice du programme, Mme Caroline Pagé et bénéficient ainsi d'une aide pour intégrer le marché du travail canadien. Cette réintégration des participants au marché canadien du travail complétera le programme de stages internationaux édition 2000.

\section{Activités à la Forêt expérimentale}

Comme à chaque saison estivale, la FE de l'ÉSF frétille d'activités s'insérant dans trois volets d'action soit l'éducation, la démonstration et la recherche.

Pour le volet éducation, la FE a été l'hôte de camps d'été en sciences environnementales durant 5 semaines. Également plusieurs visites guidées ont eu lieu principalement pour les élèves de la région. La FE a également été explorée par des organismes étrangers soit la Maine Géographique Alliance et la Temperate Forest Fondation.

Concernant le volet démonstration, les dirigeants de la FE ont instauré la culture de champignons comestibles, Shiitake et
Oyster, mettant ainsi en évidence les multiples possibilités d'utilisation d'une forêt. Également, des démonstrations d'exploitation à l'aide de chevaux et de VTT ont fait la preuve qu'il était possible d'exploiter de façon rentable la matière ligneuse sans toutefois endommager outre mesure les autres ressources et leur habitat.

Dans le cadre du volet recherche et expérimentation, plusieurs dispositifs parrainés par des professeurs de l'ÉSF furent installés. Parmi les dispositifs, on retrouve un test de provenance du mélèze, une évaluation de l'influence de la couleur du paillis sur la croissance des conifères et la mise en place d'une minipépinière résineuse.

L'ensemble de ces activités a permis de créer plus de 20 emplois dans la région. D'autres projets sont également en branle. Cette frénésie à la FE témoigne de son importance pour la région et de son implication constante dans la collectivité. La Forêt expérimentale fêtera d'ailleurs cette année ses 10 ans d'existence !

\section{Congrès de I'IFC}

Chaque année, en collaboration avec la section maritimes de l'IFC, l'ÉSF offre la chance à un étudiant ou une étudiante de participer au congrès annuel de l'IFC. En ce 92ième congrès, Mme Michelle Ouellette a eu l'opportunité de se rendre à Terre-Neuve pour ainsi assister à de nombreuses conférences et visites terrain.

Cette expérience lui a entre autres permis de se familiariser avec la foresterie de Terre-Neuve, de rencontrer des professionnels et d'autres étudiants. C'est une chance inoubliable pour les étudiants de se frotter au monde scientifique mais également de découvrir d'autres coins du pays.

\section{Les étudiants coop en stage}

Un groupe de nos étudiants inscrits au programme coopératif en sciences

\title{
Section News / Nouvelles des Sections
}

\section{Klondike}

The Klondike Section of the Canadian Institute of Forestry presented its first ever Gold Medal to Peter Wright, a recent honours graduate of the Yukon College Renewable Resource Program in Whitehorse. Peter's outstanding academic performance made him the top studient in the country in a forestry or renewable resource program.

Prior to arriving in the Yukon in 1996, he obtained a diploma in Ski Resort Operation Management, and practised his newly learned skills at resorts in Japan and B.C. Since living in the Yukon, Peter has worked in a variety of forestry-related jobs. $\mathrm{He}$ 's also been very involved in numerous community programs. Peter is a paramedic, volunteers as an auxiliary with the RCMP and is a firefighter with the Whitehorse Fire Department. He also serves on CPR Yukon's board of directors and is a member of the Young Rider program to promote safe snowboarding.

In his spare time, Peter enjoys skiing, snowboarding, mountain biking and golfing. Peter hopes to find full-time employment in the renewable resource field and remain in the Yukon.

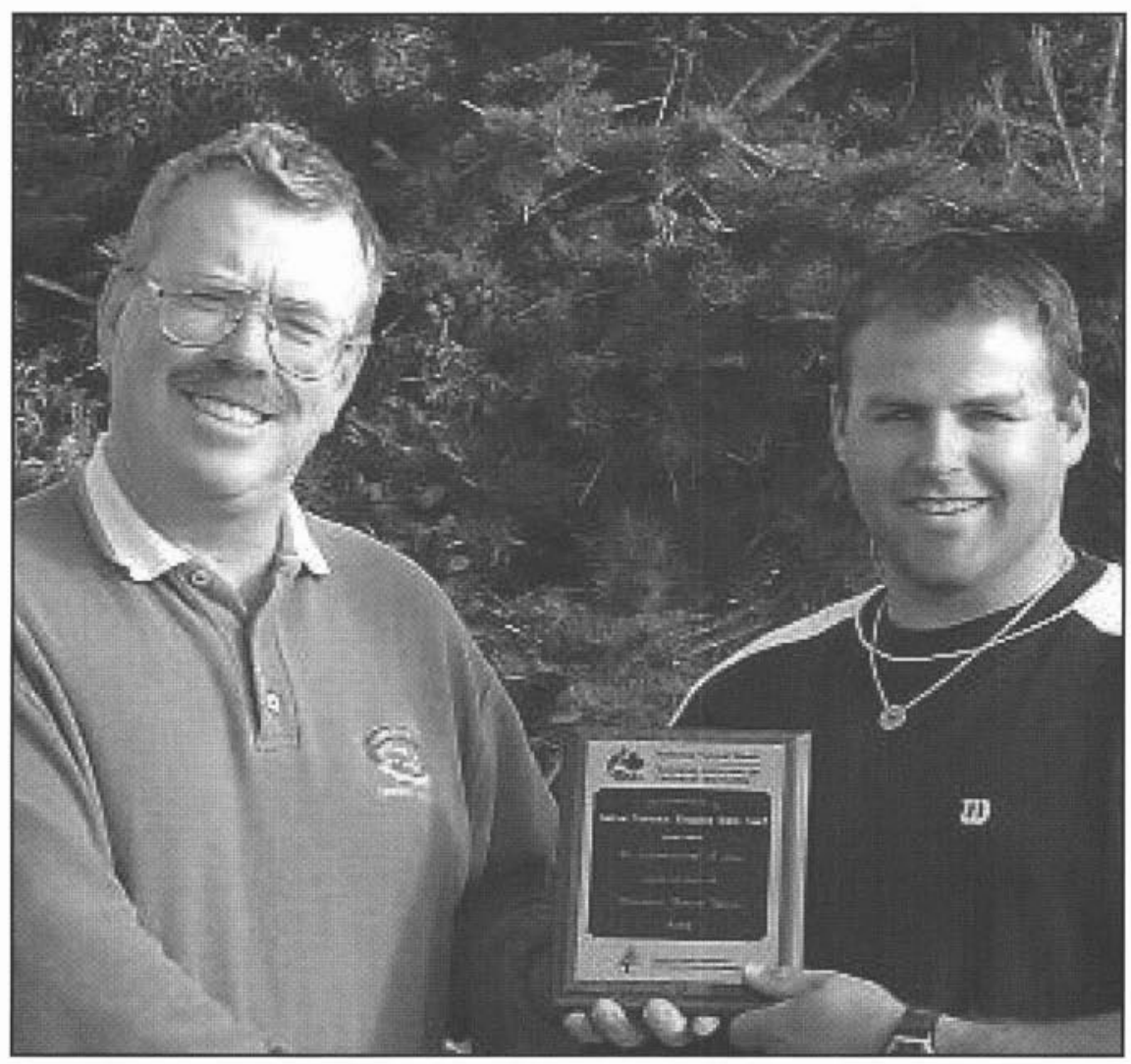

Jeff Monty (left) Chair of the Klondike Section presenting the Gold Medal Award to Peter Wright. 
forestières sont à effectuer leur troisième stage en milieu de travail. Trois d'entre eux effectuent un stage en sylviculture soit Jérôme Pelletier chez J.D. Irving à Deersdale, Amanda Khan au Ministère des Ressources naturelles et de l'Énergie à Fredericton et Charles Sirois chez RègeNord à Kedgwick. Deux autres étudiants vont quant à eux travailler dans les opérations forestières soit Patrick Cormier chez Denizo Lebel à St-Quentin et Michel Leblanc chez Produits Forestiers Donohue à Baie-Comeau au Québec. Finalement Cynthia Doiron abordera au cours de son stage le contrôle de la qualité à l'usine de J,D. Irving de St-Léonard. Merci à tous les employeurs qui permettent la tenue de ce stages, un aspect important dans la formation de futur(e)s ingénieur(e)s forestier(e)s.

\section{Internationalisation des études}

L'École de sciences forestières (ÉSF) est très heureuse d'annoncer que Mme Marie-Ève Landry, une de ses étudiantes de quatrième année, est bénéficiaire d'une bourse internationale CIME (Cursus intégrés pour la mobilité des étudiants) de l'Agence universitaire de la Francophonie (AUF). Cette bourse va permettre à Mme Landry de parfaire sa formation à la Faculté des sciences agronomiques (FSA) de l'Université catholique de Louvain (UCL) en Belgique. Ainsi, dès janvier 2001, Mme Landry suivra des cours à l'UCL qui lui seront reconnus comme équivalence dans son baccalauréat en sciences forestières.

En janvier 2000, l'Université de Moncton, l'UCL et l'AUF signaient une entente CIME, ce qui permettait l'éligibilité des étudiants de l'ÉSF aux bourses CIME. La bourse CIME est attribuée pour une durée de 6 mois et couvre les dépenses d'avion, de séjour et d'installation en Belgique.

Dans le cadre d'une entente d'échanges d'étudiants et de professeurs signée en 1987 entre l'ÉSF et la FSA, Mme Landry est la troisième étudiante de l'ÉSF à se rendre à l'UCL.

L'ÉSF tient à souligner la précieuse contribution d'un de ses professeurs, M. Jean-Marie Binot, dans ce dossier. Ses liens avec l'UCL ont contribué à l'internationalisation de l'ÉSF et sa collaboration dans le dossier des ententes institutionnelles a permis à des étudiants et étudiantes de l'ÉSF de vivre une expérience internationale.

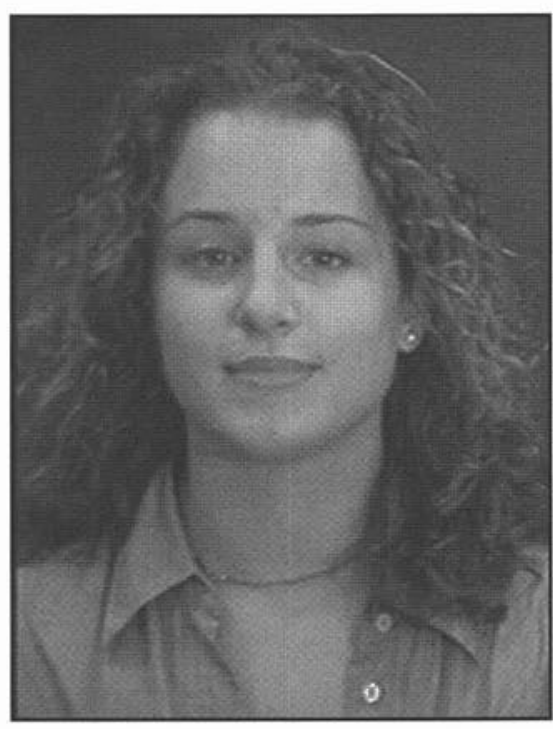

Marie-Ėve Landry, etudiante de l'ESF, ira etudier a l'Universite Catholique de Louvain

\section{Participation de nos éfudiants à un Forum jeunesse}

Zones côtières 2000-Forum jeunesse a permis à cinq de nos étudiants de s'illustrer sur la scène nationale. Dans le cadre de cette conférence, qui en fait regroupait des participants venus de tous les coins du monde, nos étudiants ont partagé leurs connaissances en établissant le lien entre la foresterie et les zones côtières. Ainsi, Daniel Arsenault, Patrick Cormier, Daniel Gautreau (gradué), Patrick LeBreton et Pascal Soucy (gradué) présentaient une conférence sur l'aménagement responsable des bassins hydrographiques. Lors de leur présentation, ils cherchaient à démontrer qu'une bonne gestion des bassins hydrographiques est primordiale pour le maintien des ressources halieutiques et naturelles et que cette gestion passe par de bonnes pratiques forestières.

\section{TORONTO \\ Presentations at Conferences}

Sean Thomas attended the second ever meeting of the Smithsonian Institution's Center for Tropical Forest Science (CTFS), held May 31 - June 3 at the National Institute of Education, Republic of Singapore. The roughly 100 participants in the meeting represented ongoing large-scale forest plot projects in Singapore, Malaysia, Thailand, Philippines, Taiwan, Cameroon, Dem. Rep. Congo, Panama, Columbia, and Ecuador. Thomas gave an invited talk on "Largescale forest plots and applied forest management", and led a 3-day field trip of meeting participants to Pasoh Forest Reserve in nearby peninsular Malaysia.

\section{Awards}

- Professor Paul Cooper, Chair in ValueAdded Wood and Composite Products was successful in his recent Canadian Foundation for Innovation application for research equipment funding. This support will provide funding for essential equipment for wood composites and wood preservation research including a research composites press, mechanical testing equipment and an ion chromatograph. This equipment will be used for faculty and graduate student research and is especially important for the support of students entering our new M.Sc. in Wood Engineering program offered in collaboration with the Departments of Chemical and Mechanical Engineering at the University of Toronto.

- Professor Barbara Zimmerman was awarded a grant from the Donner Canadian Foundation for development of research and forest conservation initiatives based at the Kayapo Centre for ecological studies, a biological research station run by the NGO Conservation International with the Kayapo Indian community of Aukre in the southeastern Amazon of Brazil. The objective of the Kayapo Centre for Ecological Studies is to facilitate research on tropical forest management while benefiting the Kayapo community of Aukre through employment and training opportunities and research station fees. Conservation International and the Faculty of Forestry support conservation and development with the Kayapo because this indigenous nation is protecting 13000000 ha in the southeastern Amazon from deforestation.

- Congratulations to Dr. Martin Hubbes for receiving the Canadian Institute of 
Forestry/Institut forestier du Canada Canadian Forestry Scientific Achievement Award. Throughout his career, he has been a highly active and energetic researcher, who has contributed many scientific papers of fundamental importance and has established an international reputation as a leader in application of biotechnology to forest pathology problems. Dr. Hubbes' most significant contribution has been his work on Dutch elm disease, particularly during the past eight years. There is no question that Dr. Hubbes' research has made a most important contribution to the practical control of Dutch elm disease, which has devastated urban landscapes in many parts of North America and Europe during the past thirty years. The Award was presented during the CIF/IFC annual meeting in Corner Brook, Newfoundland.

\section{Graduate Degree Recipients}

Congratulations to our newly minted graduates and their supervisors.

- Misra, Dinesh, MScF. Early tree-soilroot relationships of Prosopis, Eucalyptus and Azadirachta planted on sodic soils. (V.R. Timmer)

- Shi, Haijin, MScF. Growth models of sugar maple forest in southern Ontario. (S. Kant)

- Ahmed, Gias Uddin, MScF. Sustainable forest management under uncertainty. (D.L. Martell)

- Doka, Margaret, MScF. Impact of silvicultural practices on insect communities and herbivory on young jack pine in northern Ontario. (S.M. Smith and I. Bellocq)

- Duffy, Natasha. MScF. Design limitations to potential leaf area in urban forests. (W.A. Kenney)

- Khomasurya, Tarcisia, MScF. Characterization of the essential oil of Thuja occidentalis leaves and branchlets. (J.J. Balatinecz)

- Quoreshi, Ali, PhD. Nutritional preconditioning and ectomycorrhizal formation of Picea mariana (Mill.) B.S.P. seedlings. (V.R. Timmer)

- Imo, Moses Owade, PhD. Vector competition analysis: a model for evaluating interspecific plant growth and nutrient interactions in cropping systems. (V.R. Timmer)

- Williams, Gregory R. PhD. Polymer fibre reinforced thermomechanical pulp (TMP) based papers. (J.J. Balatinecz)

Amalia Veneziano

\section{ALBERTA}

The University of Alberta's forestry programs have had a productive year, indicated by significant industry and government support for new scholarships and research programs.

In January, the BSc Forestry and BSc Forest Business Management programs were RPF accredited by the Canadian Forestry Accreditation Board for 6 years, making them the prairie provinces' only nationally accredited forestry programs.

The University is also proud to announce the appointment of Dr. Vic Lieffers as the NSERC Weldwood/Weyerhaeuser Industrial Research Chair in Silviculture in Enhanced Forest Management. This prestigious position was made possible through generous investments from Weldwood, Weyerhaeuser and the National Sciences and Engineering Research Council. The U of A's silvicultural research is groundbreaking and some of the tree sway research is unique worldwide.

Drs. Bruce Dancik and Francis Yeh each received International Union of Forestry Research Organizations (IUFRO) Scientific Achievement Awards. This award has never been presented to two Canadians since its inception in 1971 and only four Canadians have ever won the award. Dr. Wei Rung Peng also won the IUFRO - Outstanding Doctoral Research Award.

Bruce Buchanan, former owner of Sunpine Forest Products, donated \$250000 in the name of J.A. (Al) Brennan for graduate Scholarships.

A number of new staff members joined the U of A Renewable Resources teaching and research team:
Dr. Phil Comeau, Professor of Silviculture and Stand Dynamics

Dr. Glen Armstron, Professor of Landscape Forestry and Integrated Resource Management

Dr. Peter Boxall, Professor of Resource/ Environmental Economics

Dr. Les Fuller, Chair in Environmentally Sustainable Agriculture

Dr. Debra Davidson, Professor of Environmental, Resource, and Forest Sociology Dr. Lee Foote, Professor of Ecology

Alex Drummond, Coordinator of Forestry Field Schools

Dr. Francis Yeh has been appointed Associate Dean (Research) for the Faculty of Agriculture, Forestry, and Home Economics, taking over responsibilities from Dr. Paul Woodard who returns to his teaching and research in the Department of Renewable Resources.

Four undergraduate forestry students were awarded scholarships to attend the 1999 CIF AGM conference held in Banff, which was well attended by Renewable Resources department staff and the Dean of the Faculty.

Two successful Forest Industry Lecture Series presentation were hosted in the academic year. This years speakers were Dr. Reinhard F. Stettler ("The Question of Scale in the Management of Poplar") and Dr. Shin Nagata ("Japanese forests to make Japanese houses").

Forty Forestry and Forest Business Management students attended the March 2000 Silver Ring Ceremony and graduation banquet with guest speaker Mike Cardinal, Associate Minister of Forestry.

The University looks forward to continued growth and success in forest research and teaching in the 2000-2001 academic year.

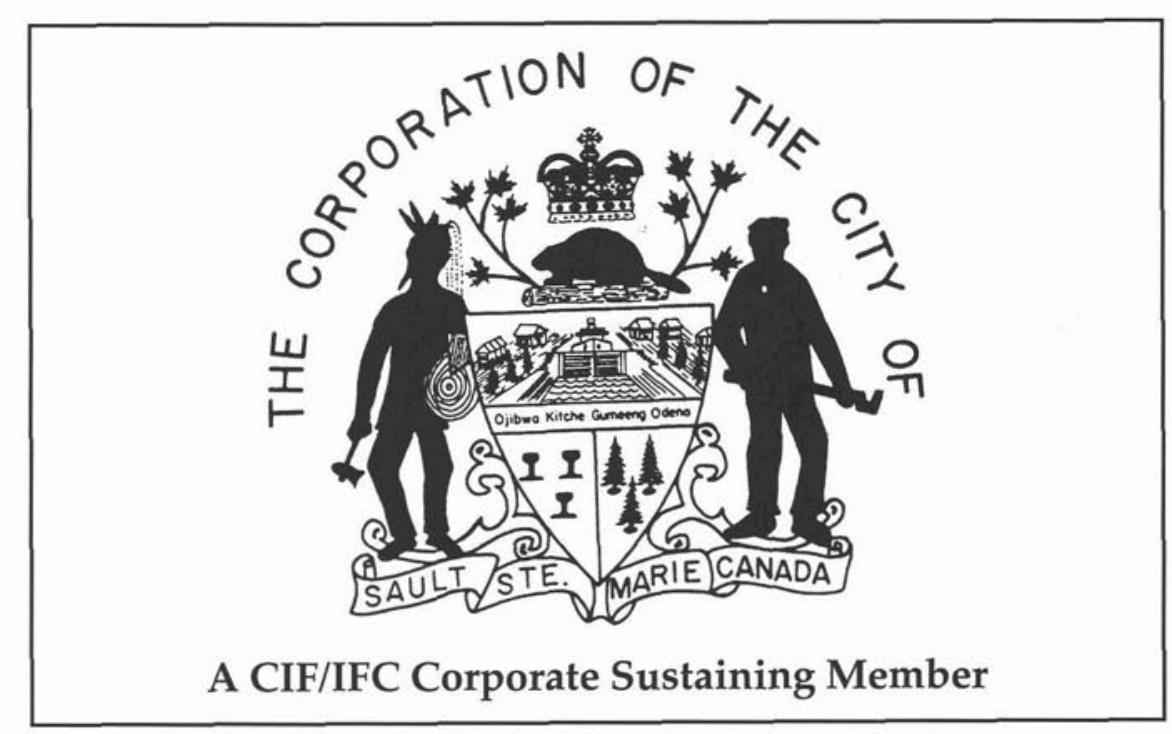




\section{NORTHERN BRITISH COLUMBIA}

Students

On March 10 the $5^{\text {th }}$ annual Ring Ceremony was held at the Columbus Hall in Prince George for students graduating in April 2000. A total of 88 candidates received rings and the hall was filled to capacity with faculty, family and special guests. The Cariboo Section of the CIF sponsored the event and a description of the evening's activities can be found in the May/June 2000 issue of The Forestry Chronicle. The CIF gold medal was awarded to Katrina Froese who also received a special award from the Forestry Program for her academic performance. Katrina begins a Masters degree at UNBC this fall under the supervision of Oscar Garcìa, Endowed Chair of Growth and Yield.

The UNBC convocation ceremony was held on May $26^{\text {th }}$, and 81 students were granted the BSc in Natural Resources Management (Forestry Major). First year enrolments are down from last year but the total number of undergraduate students enrolled in Natural Resources remains steady at 430 compared to 436 last year (285 and 319 declared Forestry Majors, respectively). Graduate students working on natural resource related topics has increased to 64 students.

\section{Faculty and Staff}

The Forestry Program is very pleased with the appointments of two Endowed Chairs. Dr. Chris Hawkins has been appointed to the Endowed Chair in Mixed Wood Ecology, and Dr. Oscar García is the Endowed Chair in Growth and Yield. A Forest Extension Officer (Nicole Wilder) has been hired to assist the chairs with research, administrative and extension duties. Nicole brings extensive experience with Forest Renewal BC and project management to the Endowed Chair program.

Dr. Hawkins was formerly the Silviculturist in the Forestry Program and his general research interests are regeneration silviculture, population biology and forest productivity. Topics he is currently investigating include: silviculture and genetic testing of spruce, embling (somatic embryogenesis) clones; population biology and physiology of paper birch; regeneration silviculture of seed orchard conifer seedlings and hybrid poplar; effects of site preparation on long term site productivity; biology of lodgepole pine natural regeneration; economic impacts of silvicultural decisions; and nursery culture and field performance of planted seedlings.

Professor García holds a PhD in Forest Resources from the University of

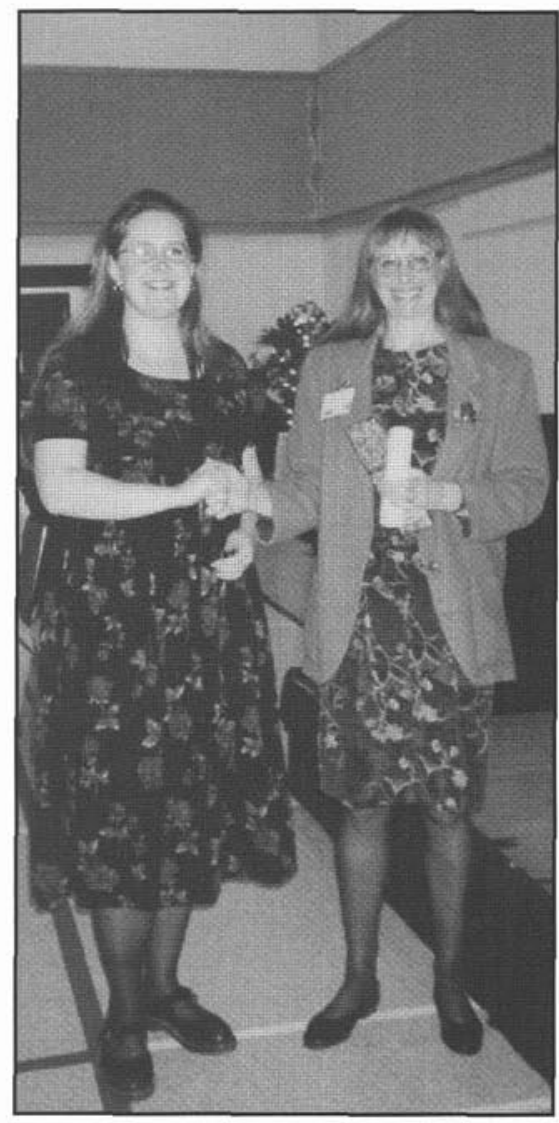

Katrina Froese (leff) receives the Forestry Program's Academic Achievement award from Dr. Wini Kessler. Katrina was also the recipient of the CIF Gold Medal.

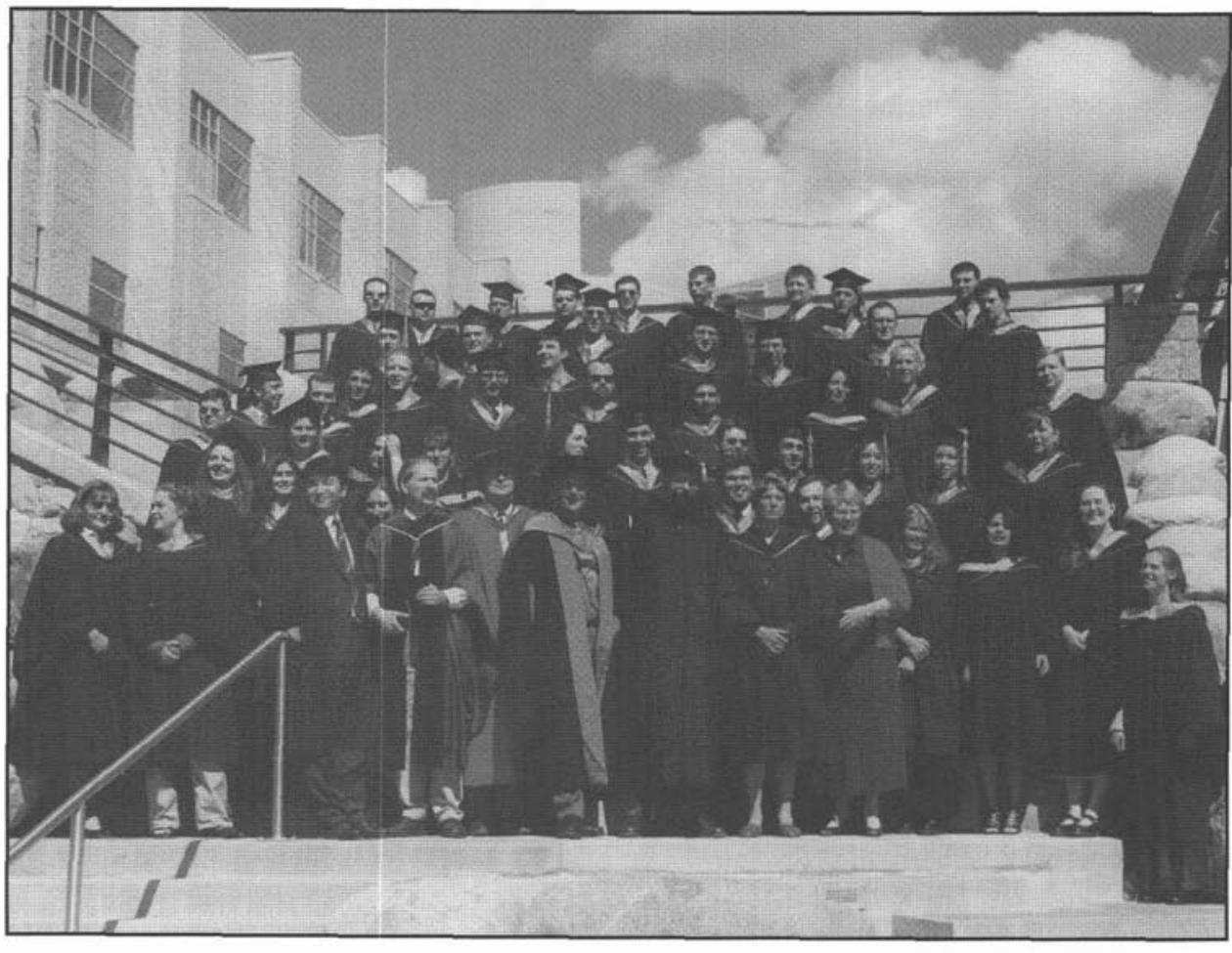

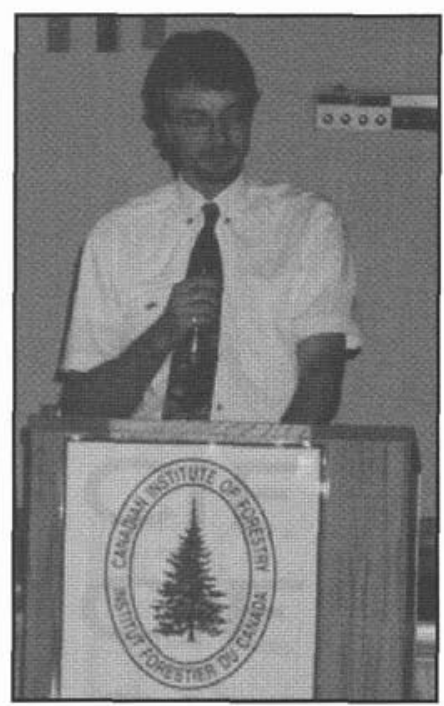

Colin Chisholm speaks on behalf of the 2000 graduating class at the 5 th annual CIF Ring Ceremony.

The year 2000 graduating class and faculty members during convocation. 
Georgia, USA, and both a MSc in Mathematical Statistics and Operations Research and a professional forester degree (Ingeniero Forestal) from the University of Chile. Between 1976 and 1992 he worked in New Zealand for the Forest Research Institute, developing forest management planning decision-support systems and being responsible for much of their plantation growth modelling program. Later, he led a Government/Industry cooperative eucalypt modelling project in Chile, and conducted forest planning research in Spain for the Galician Government. He also occupied the Chair of Forest Mensuration at the Austral University of Chile, and held Visiting Professor positions in France, Denmark, and Spain.

We are also pleased with the reappointment of Dr. Brad Hawkes (Canadian Forest Service, Pacific Forestry Centre) and Dr. Ian Hartley (Forintek Canada Corp.) as Adjunct Professors. Dr. Robert Lackey, associate director for science at the U.S. Environmental Protection Agency in Corvallis, Oregon, was a visiting Fulbright scholar for six months in 1999. He worked with Dr. Kessler on the relationship between ecological science and public policy. The Chair of the Forestry Program, Dr. Winifred Kessler has taken a one-year leave of absence to work with the US Forest Service in Juneau, Alaska. Dr. Kathy Lewis has been appointed Acting Program Chair for the year. Dr. Staffan Lindgren, and Associate Professor in the Forestry Program, continues to be the Acting Chair of the Biology Program, and was awarded a special merit award for outstanding service to the university. Dr. Kathy Parker (Associate Professor in the Forestry Program) has returned from sabbatical where she worked on the nutritional ecology of caribou. She has recently been awarded the Ian McTaggart-Cowan Muskwa-Kechika Research Professorship.

Two members of the Forestry Program were evaluated for promotion and/or tenure this year and both were successful. Dr. Art Fredeen was tenured and promoted to Associate Professor, and Dr. Stephen Dewhurst received tenure.

The I.K. Barber Enhanced Forestry Lab officially opened March 2, 2000. The \$1.6million I.K. Barber Enhanced Forestry Laboratory is a 7900 square-foot facility with four separate greenhouse compartments for plant growth and yield experiments. There is also a lab for experiments on soil composition and nutrients. Two

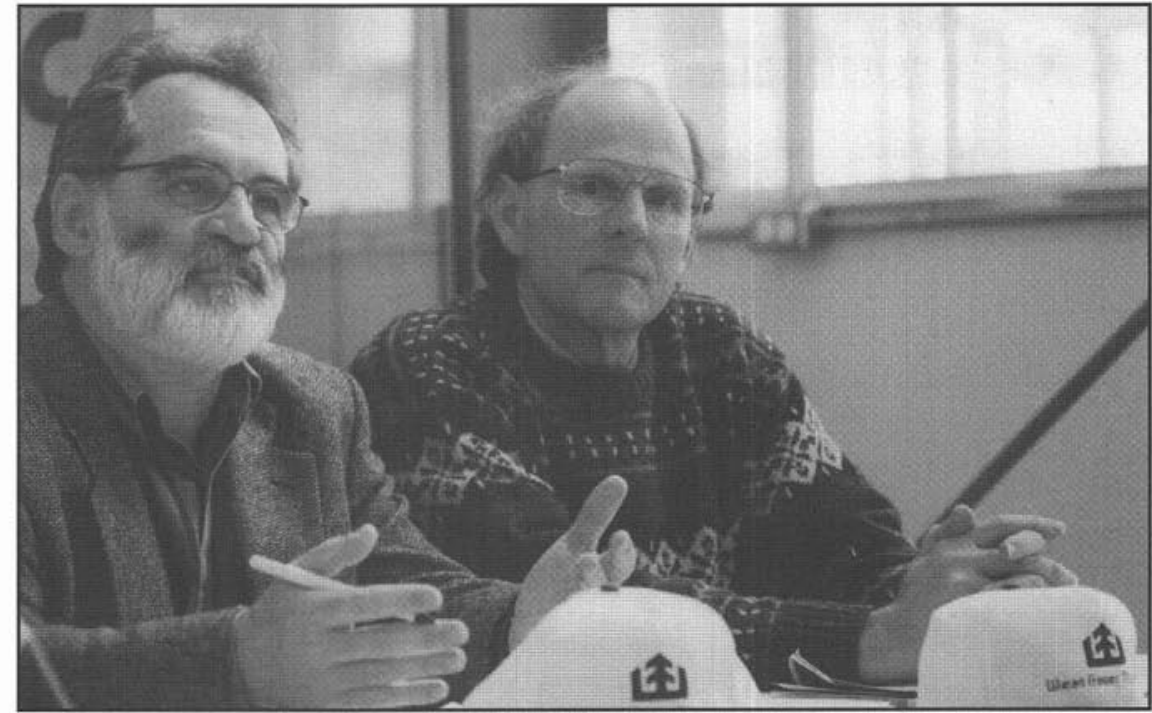

Dr. Oscar García, Chair of Growth and Yield (left) and Dr. Chris Hawkins, Chair of Mixedwood Ecology (right). people (John Orlowsky and Steven Storch) have been hired to manage this facility as well as the instructional greenhouse. This facility and its managers, have already proven to be a tremendous asset to research and teaching within the Forestry Program. The hiring of Roy Rea as Senior Lab Instructor in the
Forestry Program has further enhanced our teaching capability. Roy is well qualified for this position as he not only completed his masters degree at UNBC in the area of wildlife/forestry interactions, but was also recognized with an award for outstanding teaching during his tenure as a teaching assistant.

\section{BRITISH COLUMBIA}

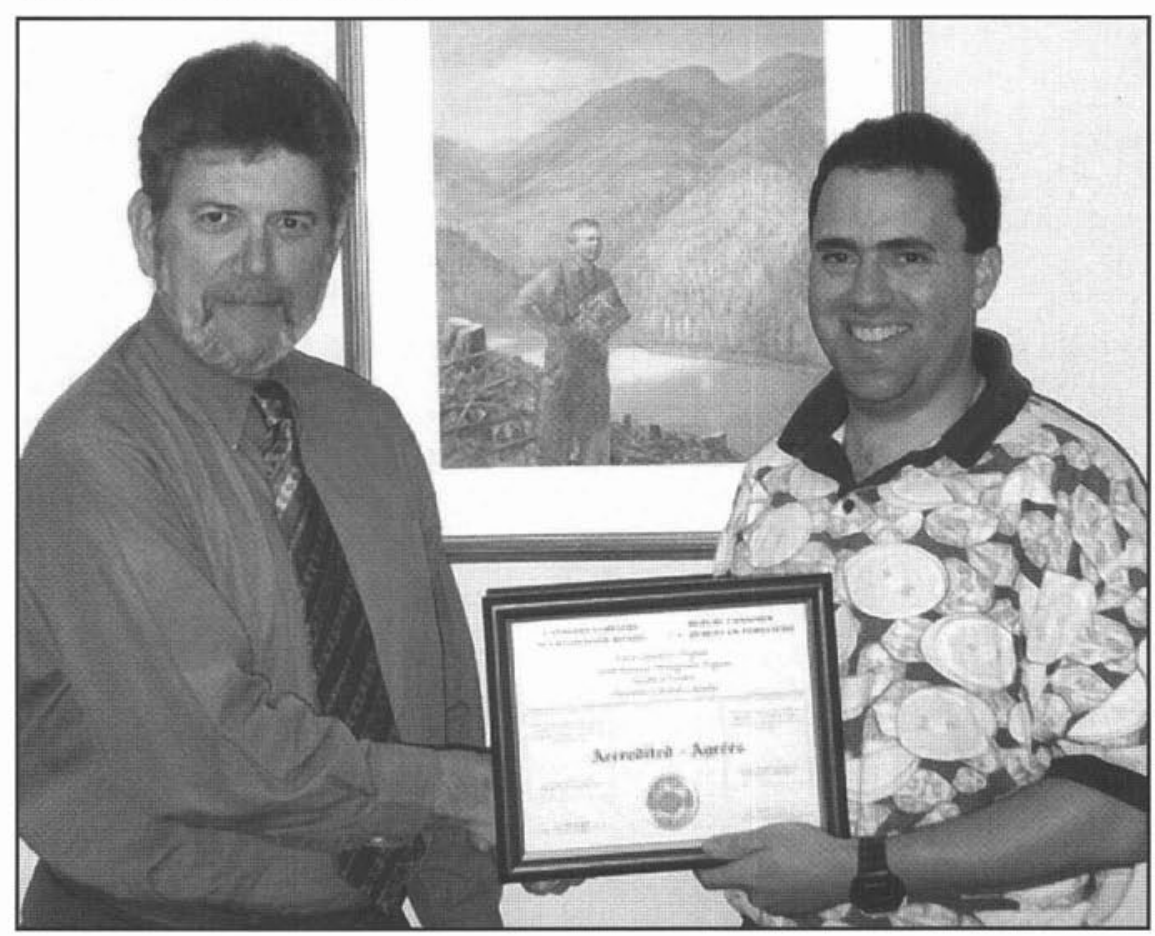

Alternate member Jerome Marburg (right) presents a Canadian Forestry Accreditation Board certificate to Acting Dean John Mclean, Faculty of Forestry, University of British Columbia, to mark the national accreditation of the Faculty's Forest Resources Management and Forest Operations Programs. 